\title{
Fulgurações subversivas de uma poética (m)enor(me)
}

\author{
Kim Amaral Bueno ${ }^{1}$
}

\begin{abstract}
This article aims to understand the formal hybridity of the contemporary epic Uma Viagem à Índia by Portuguese writer Gonçalo M. Tavares. The hypothesis developed is that the literary work represents the resistance of a model considered dead by important authors of modernity, namely, the epic, through intertextuality with this discourse notably "major". The fictional/poetic devices activated by Tavares' text produce a point of subversion inside discourse himself that enables, finally, to read Uma Viagem à Índia through a "minor literature", category developed by Deleuze \& Guattari, especially in Kafka: Toward a Minor Literature (1975).
\end{abstract}

Keywords: Gonçalo M. Tavares; Portuguese Contemporary Literature; epic discourse; intertextuality.

Resumo: Este estudo deseja compreender o hibridismo formal do épico contemporâneo Uma viagem à Índia, do escritor português Gonçalo M. Tavares. A hipótese desenvolvida é a de que a obra representa a resistência de um modelo considerado morto por importantes pensadores da modernidade, a saber, o épico, por meio da intertextualidade com esse discurso notadamente "maior". Os dispositivos ficcionais/poéticos acionados pelo texto tavariano produzem um índice de subversão no interior do próprio discurso que possibilita, por fim, ler Uma viagem à Índia sob o viés de uma "literatura menor", categoria desenvolvida por Deleuze \& Guattari, sobretudo em Kafka: por uma literatura menor (1975).

Palavras-chave: Gonçalo M. Tavares; Literatura portuguesa contemporânea; discurso épico; intertextualidade.

Introdução

Gonçalo Tavares nasceu em 1970 na cidade de Luanda, porém ainda criança foi viver em Lisboa, constituindo-se português por formação e afeição. É nítida a dicção europeia que reverbera em suas obras. Talvez muito mais europeia do que portuguesa, numa sensível "negação" da questão nacional em nome de uma equação universal. A publicação de sua primeira obra, O livro da dança, data de 2001. O título já é indicativo de uma das preocupações sobre as quais Tavares vai se debruçar, a saber, as relações entre o corpo, o espaço, o tempo, a memória e a história, encarnadas pelo movimento, seja o dos sujeitos individuais ou o das sociedades. Após essa publicação de 2001, seguiramse outras dezenas de títulos divididos em segmentos de continuidade, uma espécie de "séries", que, por sua vez, constituem-se por "cadernos": há os livros de "O Bairro", nos quais há a produção de um bairro ficcional no qual se avizinham alguns dos grandes escritores universais, os "Senhores", tais como O Senhor Valéry, O Senhor Henri, O

1 Doutor em Letras/Literatura Comparada pela Universidade Federal do Rio Grande do Sul - UFRGS. Professor do Instituto Federal de Educação, Ciência e Tecnologia Sul-rio-grandense - IFSul. 
Senhor Brecht... totalizando, por enquanto, dez "Senhores"; há, também, os de "O Reino", série composta por quatro romances de densidade textual bastante significativa, entre os quais está "Jerusalém" (2004), obra de grande repercussão crítica. Há, ainda, outras “séries" elencadas pelo autor para agrupar a sua obra, possuindo, essas, um número mais reduzido de títulos. São elas: Investigações, Teatro, Bloom Books, Poesia, Arquivos, Estudos Clássicos, Canções, Enciclopédia, Cidades, Epopeia, Short Movies e Atlas.

Muito embora os autores não estejam "mortos" (como se poderia supor ao ler o célebre texto de Foucault), e sim mais vivos do que nunca neste século XXI de intenso espetáculo midiático, prefiro que ouçamos a sua obra e aquilo que ela, porventura, venha a nos falar sobre si e sobre o seu criador, e não o contrário. Portanto, quero rapidamente comentar, do ponto de vista diegético, poético e formal, algumas dos textos de Tavares identificados na tabela mencionada, para, na seção seguinte deste introito, realizar um pequeno levantamento crítico (pequeno porque parcial, uma vez que, dos trabalhos acadêmicos que identifiquei sobre a obra de Gonçalo M. Tavares, dispus-me a citar apenas os que mais me afeiçoaram teórica e esteticamente) depreendendo algumas importantes chaves de leitura, que, obviamente, corroboram à minha, abstendo-me de maiores comentários biográficos acerca do autor. Sobre o procedimento de construção desta poética caleidoscópica, dividida em cadernos dispostos em séries, é possível afirmar que o autor se situa, nele, como um cartógrafo que se propõe a mapear as deambulações da linguagem, apreendendo o seu pensamento, sempre em trânsito, numa poética que celebra o inacabado e o descontínuo, numa postura que francamente rejeita as certezas, propondo-se a indagar e a investigar continuamente a literatura/a arte/a linguagem, rearranjando-a constantemente em objetos que se situam num território poético sedimentado pelo fragmento, pela citação, pela especulação epistêmica, pelas ligações transtextuais e pela negação das fronteiras entre poesia lírica, narrativa ficcional e ensaio filosófico.

Uma viagem à Índia (2010) é obra peculiar dentro do projeto literário de Gonçalo M. Tavares, autor português nascido em 1970. Suas quase quinhentas páginas poetizam/ narram as peripécias de Bloom, protagonista que se lança em viagem de Lisboa rumo à Índia com a finalidade de esquecer a tragédia que lhe acometera: o assassinato da mulher amada por ordem do pai e o assassinato do pai por ele mesmo premeditado como vingança. De matriz extremamente transtextual, a grande viagem operada na obra é sem dúvida aquela que percorre a tradição cultural do Ocidente, cujos empréstimos são verificáveis desde o nome do protagonista, Bloom (nome que retoma o personagem de James Joyce, Leopold Bloom, em Ulysses, que, por sua vez, remete-nos ao personagem homérico da Odisseia, produzindo um circuito transtextual explícito no qual Uma viagem à Índia é o motor hipotextual), passando pela confissão contida no título sobre o tema ao qual tratará, o da viagem (e, uma viagem à Índia, lembrando as navegações portuguesas do final do século XIV) e chegando na sua estrutura a espelhar aquela de Os lusíadas, com sua divisão em estrofes e cantos.

A formatação do texto a partir do paradigma da epopeia camoniana e da confrontação explicita com a herança cultural do passado, faz com que Eduardo Lourenço, no prefácio à primeira edição de Uma viagem à Índia (2010), considere-o um "prosaico poema, antipoema e hiper-poema, com consciência aguda da sua ficcionalidade, [que] navega e vive entre os ecos de mil textos-objetos do nosso imaginário de leitores". A alusão à categoria de Gérard Genette (1982) de "hipertexto" parece bastante apropriada à obra de Tavares, tanto pela conexão com seu hipotexto imediato, Os lusíadas, mas também pelas "referências 
hiper-literárias", num diálogo tanto com os textos da tradição épica clássica quanto com o moderno Joyce. Lourenço (2010) oscila entre se referir ao texto como um "romancepoema" ou um "poema-romance", mas não se furta de lhe atribuir um poder premonitório, "futurista", através de seu "anacronismo paradoxal", produzindo nele uma nova dobra a expor a força do seu ambivalente dispositivo épico/anti-épico: a cadeia de referências do passado em franca subversão indicam uma "negrura absoluta" (pessimista), marca desta "viagem à Índia, pátria arcaica de nós mesmos como Espírito, entre fantasmas e vampiros de que esta cruel e tónica Viagem se alimenta" (LOURENÇO, 2010, p. 7-11) .

A tarefa deste estudo será a de compreender em que concerne o hibridismo formal encarnado por esta forma épica na qual o texto se apresenta. A hipótese a ser desenvolvida é aquela que o compreende enquanto exemplar de um discurso épico contemporâneo, diferindo de uma compreensão clássica por meio do gênero épico de viés aristotélico. Tal discurso engendraria um substantivo componente lírico a arrefecer a narrativa. A resistência, em Gonçalo M. Tavares, de um modelo considerado morto por importantes pensadores da modernidade, e os dispositivos literários engendrados pelo autor na subversão deste modelo de discurso notadamente "maior" produzem um índice de subversão no interior do próprio discurso que possibilita, por fim, ler Uma viagem à Índia sob o viés de uma "literatura menor", categoria desenvolvida por Deleuze \& Guattari, sobretudo em Kafka: por uma literatura menor (1975).

\section{Intermitências luminosas de um discurso sobrevivente}

A ideia de "sobrevivência" que atribuo ao discurso épico no contemporâneo, encarnado aqui por Uma viagem à Índia, foi obtida por meio da obra de Georges Didi-Huberman chamada Sobrevivência dos vaga-lumes (2011), na qual o filósofo francês parte de uma passagem do "Inferno", da Divina Comédia de Dante, e de dois textos de Pasolini, para formular a metáfora que alimentará a sua tese, a saber, aquela dos vaga-lumes como um símbolo de resistência político-poética frágil, delicada, em meio a um contemporâneo sombrio, de reverberação fascista, aparentemente incontornável ${ }^{2}$. Assim, as questões levantadas por Didi-Huberman que nortearão a sua ulterior reflexão teórica são as seguintes: (1) "Mas no que se tornaram hoje os sinais luminosos evocados por Pasolini, em 1941, e, em seguida, tristemente revogados em 1975?”; (2) “quais são as chances de aparição ou as zonas de apagamento, as potências ou as fragilidades?"; e, (3) "a que parte da realidade - o contrário de um todo - a imagem dos vaga-lumes pode hoje se dirigir?” (DIDI-

2 O primeiro texto de Pasolini, otimista, é uma carta de 1941, comentando um trecho da Divina Comédia, na qual o cineasta percebe na escuridão do Inferno dantesco, da vala dos conselheiros pérfidos, pequenas iluminuras - a intermitência dos vaga-lumes -, numa forma de esperança em meio ao ápice do fascismo; o segundo, de 1975, pessimista, verifica a morte dos vaga-lumes constatados na juventude em meio ao alto-fascismo. No rastro de Walter Benjamin e Guy Debord, Pasolini postula o extermínio dos vaga-lumes nos ofuscantes holofotes da mídia e do fascismo como uma espécie de extermínio do povo em sua aspiração por justiça social. O extermínio das utopias e do amor numa "época de ditadura industrial e consumista em que cada um acaba se exibindo como se fosse uma mercadoria em sua vitrine, uma forma justamente de não aparecer". A síntese possível a que Didi-Huberman nos encaminha a partir da carta de 1941 e dos artigos dos anos de 1970, sobretudo àquele específico do "desaparecimento dos vaga-lumes", atravessando a ideia de "genocídio cultural" é a de que "os vagalumes desapareceram", de modo que "os vaga-lumes desapareceram, isto quer dizer: a cultura, em que Pasolini reconhecia, até então, uma prática - popular ou vanguardista - de resistência tornou-se ela própria um instrumento da barbárie totalitária [...]” (DIDI-HUBERMAN, 2011, p. 37-41, grifos do autor). 
HUBERMAN, 2011, p. 43). Diante de tais questões, Didi-Huberman se empenhará em diagnosticar as sobrevivências destas imagens lampejantes através de artistas cujas práticas imagético-literárias constituem-se como movimentos de uma poética menor a resistir aos gigantismos do presente, os espetáculos da mídia, da política e do capital.

A postulação das sobrevivências segue o rastro de uma obra de Denis Roche, La dispartition des lucieles (1982), lida em contraponto à tese de Roland Barthes em $A$ câmara clara (1980). Enquanto Barthes fica atrelado, "enlutadamente", ao "isto foi" da imagem fotográfica, Roche percebe nas imagens o seu estado "intermitente"3: elas, enquanto objetos, dependem de seus leitores/espectadores para captar os sentidos que lampejam e que estão depositados numa forma de absoluto já realizado no ato fotográfico de "registrar". Eis, então, que o título de Roche se elucida: La dispartition des lucieles O desaparecimento dos vaga-lumes - é esclarecido como um desaparecimento somente "aos nossos olhos", de modo que "seria bem mais justo dizer que eles se vão, pura e simplesmente", isto é, que "desaparecem apenas na medida em que o espectador renuncia a segui-los", recusando-se a ocupar "o melhor lugar para vê-los" (DIDI-HUBERMAN, 2011, p. 47). O empenho em procurar os vaga-lumes existentes - a despeito da acomodação de não se mover para vê-los - é lido em Denis Roche pela necessidade do fotógrafo de "fazer imagem [...] a partir de uma iluminação intermitente que é também, assim como para os vaga-lumes, uma vocação à iluminação em movimento", de modo que "os fotógrafos [seriam], primeiro, viajantes [...]: como insetos em deslocamento, com seus grandes olhos sensíveis à luz" (DIDI-HUBERMAN, 2011, p. 47).

A associação entre fotógrafos e viajantes elaborada por Denis Roche revela uma concepção de fotografia perscrutória, investigativa, perquiridora, que não se satisfaz com o imediato que nos chega aos olhos, mas que percorre espaços e avança por sítios obscuros para lhes arrancar alguma forma de luz mínima, para localizar, enfim, as formas que aparentemente desapareceram. A comparação entre fotógrafos, viajantes e insetos tem em comum os "grandes olhos sensíveis à luz"; no entanto, é possível de se imaginar uma segunda zona de contato, caso pensemos nestes insetos, os vaga-lumes, enquanto puro devir-animal; e, na câmera fotográfica, enquanto puro devir-máquina, a emitir uma luminosidade intermitente, os flashs, tal como aqueles insetos. O exemplo utilizado pelo teórico para ilustrar o argumento da necessidade de deslocamentos para a percepção e apreensão das "comunidades luminosas" - erroneamente consideradas desaparecidas -, exercício esse dos "fotógrafos viajantes" apontados por Denis Roche, é a fotografia Lucioles (2008), de Renata Siqueira Bueno ${ }^{4}$. A ausência de cores da imagem, predominantemente negra, destaca os pequenos pontos de luz pulverizados sobre a superfície disforme, manchada, a sugerir uma vegetação densa maculada por um rasgo

3 Esta posição, de movimentos antagônicos e visões, por vezes, contraditórias sobre um mesmo fenômeno artístico/estético/teorético, é típica da modernidade. Para elucidar as questões trazidas rapidamente por Didi-Huberman acerca dos autores, cf. suas obras: ROCHE, D. La disparition des lucioles: réflexions sur l'acte photographique. Paris: Éditions de l'Étoile, 1982 (não há edição traduzida para o português) e BARTHES, R. A câmara clara. Lisboa: Edições 70, 2006. Trad. Júlio Castañon Guimarães.

4 Didi-Huberman reproduz a fotografia de Renata Siqueira Bueno, Lucioles (2008), realizada na Serra da Canastra, no estado de Minas Gerais, Brasil. Resguardados das condições anômalas a sua sobrevivência afeitas às cidades, com seus "postes elétricos" que lhes instigam "comportamentos suicidas", os vaga-lumes registrados pela fotógrafa nesse parque ecológico nacional formam, exemplarmente, uma "bela comunidade luminosa", uma "comunidade anacrônica e atópica", nas palavras do filósofo francês. 
de céu acima, capturados por uma câmera trêmula, apontando para "uma comunidade anacrônica e utópica" (DIDI-HUBERMAN, 2011, p. 51), formada pelos vaga-lumes.

A imagem produzida por Renata Siqueira Bueno é extremamente lírica e delicada, porém aponta para uma potência destruidora inoculada, caso sigamos o rastro da leitura de Didi-Huberman a recorrer a uma associação entre a palavra "vaga-lume" e o "fogo que cai gota a gota [...] das bombas incendiárias, das balas riscantes, até mesmo da poeira em movimento que passa sobre as cidades japonesas bombardeadas em 1945" (DIDIHUBERMAN, 2011, p. 51). A despeito de tal energia meteórica, "é preciso cerca de cinco mil vaga-lumes para produzir uma luz equivalente à de uma única vela" (DIDIHUBERMAN, 2011, p. 52). Logo, tais constatações permitem a postulação da existência de uma "luz menor" (DIDI-HUBERMAN, 2011, p. 52) a se apropriar dos mesmos aspectos filosóficos que sustentam a existência de uma literatura menor. Isto é: nesta luz menor há "um forte coeficiente de desterritorialização; "tudo ali é político"; "tudo adquire um valor coletivo", de modo que tudo ali fala do povo e das "condições revolucionárias" imanentes à sua própria marginalização ${ }^{5}$.

A partir de Warburg e de Benjamin, Didi-Huberman cria a hipótese da imagem como "um operador temporal de sobrevivências" (DIDI-HUBERMAN, 2011, p. 119). Ela seria um instante de tempo, uma "aparição" que, embora "preciosa", é "muito pouca coisa, [é] coisa que queima, coisa que cai", semelhante à "bola de fogo evocada por Benjamin: ela apenas 'transpõem todo o horizonte' para cair sobre nós, nos atingir" (DIDI-HUBERMAN, 2011, p. 118), A retomada do texto de Walter Benjamin sobre $O$ narrador (1994) esclarece a forma como Didi-Huberman compreende a ideia de "queda", numa leitura avessa àquela desenvolvida por Agamben da afirmação benjaminiana de que "as ações da experiência estão em baixa" (BENAJMIN, 1994, p. 198): para este, "trata-se [...] de uma destruição efetuada, acabada" (DIDI-HUBERMAN, 2011, p. 120, grifos do autor); aquele, de "uma destruição efetiva, eficaz; mas é uma destruição não efetuada, perpetuamente inacabada, seu horizonte jamais fechado" (DIDI-HUBERMAN, 2011, p. 120 , grifos do autor). A extensa glosa sobre o vocabulário benjaminiano em $O$ narrador sustenta que ele é "o do declínio. Mas declínio entendido em todas as suas harmonias, em todas as suas ressurgências, que supõe a declinação, a inflexão, a persistência das coisas decaídas" (DIDI-HUBERMAN, 2011, p. 122). Ou seja, tratar-se-ia, portanto, "da questão do 'declínio' e não de desaparição efetuada": a queda concebida não como um fim absoluto e realizado, mas como um processo que, no seu ocaso, opera ciclicamente um novo começo. Para o teórico francês, a última frase de $O$ narrador - "o narrador é a figura sob a qual o justo se encontra consigo mesmo" (BENJAMIN, 2011, p. 221) -, ao empregar o tempo presente, negaria a "intemporalidade de uma definição regulada sobre o eterno ou o absoluto [, afirmando] a própria temporalidade daquilo que, hoje, entre nós, na extrema precariedade, sobrevive e se declina sob novas formas em seu próprio declínio" (DIDI-HUBERMAN, 2011, p. 123-124, grifos do autor).

\section{Estratégias minorizadoras da épica contemporânea}

Aplicando a tese de Didi-Huberman à leitura que elaboro de Uma viagem à Índia (2010) e ao efeito que a obra de Gonçalo M. Tavares produz sobre o discurso épico no

5 Cf. DELEUZE, G.; GUATTARI, F. Kafka: por uma literatura menor. Belo Horizonte: Autêntica, 2014. Trad. Cíntia Vieira da Silva. 
contemporâneo, é possível supor que a ideia de sobrevivência obtida pela relação entre a presença da luminosidade intermitente dos vaga-lumes e a necessidade de um olhar sensível a ela, bem como da relação entre fotógrafos e viajantes, persiste na elaboração do texto tavariano com seu deslocamento rumo à tradição, narrado/poetizado ao longo dos dez cantos que mimetizam subversivamente Os lusíadas, percurso este subjetivamente delineado na(s) imagem(ns) do planisfério literário contido no final do volume, através do qual o leitor deambula pela obra, exercendo, desse modo, a função de um "operador temporal de sobrevivências", assemelhando-se à descrição teórica de Didi-Huberman. Acredito que a ideia de "tempo" atrelada à imagem intermitente supõem a presença de um espaço inespecífico, afinal tal imagem aparece/desaparece/reaparece em diferentes pontos, exigindo o deslocamento do observador, sempre ativo, para a sua percepção. Imagem desterritorizalizada, o planisfério literário mobiliza o leitor por inúmeros tempoespaços dentro do narrado/poetizado, provocando o leitor a acompanhar as metamorfoses a que seus significados estão sujeitos, como argumentarei a seguir. A literatura, assim, tecida com os fios do discurso épico - contemporaneamente subversivo, e por isso mesmo, sobrevivente -, desempenha sua força de "maquina de expressão", a exemplo do que se observa na obra Dezanove recantos, da escritora Luiza Neto Jorge, (anti)epopeia que, a exemplo de Uma viagem à Índia, "minoriza" a grandiloquência épica dos discursos clássico e renascentista, demarcando a sobrevivência deste discurso no contemporâneo.

Rosa Maria Martelo, em seu ensaio Opacidades, ou nem tanto (um exemplo) (2007), analisa tal obra, os Dezanove recantos, da escritora Luiza Neto Jorge - "obra que, recordando uma tradição que parte das epopeias clássicas e passa por Os lusíadas e pela Mensagem, revê esta linhagem patriarcal, desviando-a e conduzindo-a no sentido de uma 'epopeia sumária' que a interpela e desequilibra" (MARTELO, 2007, p. 55) -, análise esta conduzida sob o viés de uma "literatura menor", considerando "o modo como esta noção procura mostrar que certas formas maiores de literatura emergem de um uso minoritário da língua" (MARTELO, 2007, p. 56). Tal "uso minoritário da língua" é atribuído por Martelo a Luiza Neto Jorge pela sua radicalização da linguagem, o que a faz estrangeira em sua própria língua, parafraseando a expressão deleuziana, de modo a conduzir a sua poesia a linhas de fuga que revelam uma "gaguez", ou seja, o uso desta língua "numa condição extrema, [a] forçar o seu estranhamento, explora[ndo]-a num plano que dela faz uma língua essencialmente nova [...], constitui[ndo] um exercício profundamente inovador e subversivo, uma forma literária de contrapoder" (MARTELO, 2007, p. 61).

O modo como Dezanove recantos se relaciona com o modelo épico "para o fazer inflectir num sentido substancialmente novo" é sintoma de sua "extrema poeticidade, bem como [de sua] radical eficácia subversiva", elementos que os tornam um "exemplo maior do uso minoritário da língua" (MARTELO, 2007, p. 64). Segundo Martelo, o projeto de Luiza Neto Jorge de uma "epopeia", na verdade,

pretendia-se uma contra-epopeia, como o evidencia o seu modo de passar sistematicamente ao lado da condição excepcional dos heróis e das acções épicas para lhes contrapor outro tipo de acções heróicas - como viver e permanecer vivo, inventar a nova face de tudo, amar desvendando, desfalsificar - que outras acções heróicas não há! (MARTELO, 2007, p. 65).

A subversão do modelo épico realizada pelos Dezanove recantos parte do título da obra, que alude "aos dez cantos da epopeia camoniana para logo os desequilibrar numa 
duplicação imperfeita (dez mais dez menos um) e numa repetição que, refazendo os cantos (em re-cantos), sugere pretender retomá-los numa escala menor, privada" (MARTELO, 2007, p. 66); ela atinge, também, a evocação de "uma forma [...] nada canônica, [...] [d] o tema da viagem na epopeia de tradição clássica", aludindo, por exemplo, a estação Sèvres-Babylone do metrô de Paris, colocando o leitor em contato com

a movimentação de uma massa humana heterogênea, feita de pessoas conduzidas por sentimentos e propósitos muito díspares [...], como uma espécie de catálogo do humano, digno de ser [...] cantado/contornado sob a forma de uma epopeia dos heróis comuns da vida comum. (MARTELO, 2007, p. 68).

Para Rosa Maria Martelo, a obra de L. N. Jorge repudia “a visão totalizadora e teleológica" das epopeias clássicas, constituindo-se sob a forma "de diferentes fragmentos de diferentes reinos ou estados da matéria, precipitando-os uns sobre os outros [...], num interminável jogo de espelhos paralelos" (MARTELO, 2007, p. 70). A "antidiscursividade" que caracteriza a geração de Poesia 61 não impede a "narratividade" empregada em Dezanove recantos, nem, como afirma Martelo, "significa qualquer menosprezo ou desatenção pelo mundo" (MARTELO, 2007, p. 70). Na obra de L. N. Jorge,

o choque no plano semântico e sintático, as elipses, as descontinuidades, a ausência de sequencialidade, a sugestividade das imagens, os neologismos obtidos por estranhas aglutinações sintáticas ambivalentes são formas de produzir uma epopeia capaz de cantar uma heroicidade ao mesmo tempo íntima e pública, uma heroicidade que interpela o mundo público a partir do mundo íntimo e que é menos a dos feitos do que a do a fazer-se. (MARTELO, 2007, p. 70).

Assim, a problematização final colocada por Martelo sobre os Dezanove recantos e sua força subversiva do modelo épico clássico por meio de uma linguagem radical e limítrofe, é aquela que questiona "como poderia ser cantado o que é da ordem difusa das intensidades e do desejo senão através de um uso minoritário da língua?” (MARTELO, 2007, p. 70). É flagrante o fato de que tal "ordem difusa das intensidades e do desejo", potência atribuída pela pesquisadora portuguesa à matéria literária de Luiza Neto Jorge, também é a tônica na (anti)epopeia de Gonçalo M. Tavares, Uma viagem á Índia (2010), texto cujo elenco de precursores igualmente incluiu Camões e Fernando Pessoa, autores de profundas reverberações do discurso épico. Logo, o que resta é acolher a interrogação de Rosa Maria Martelo também no âmbito da obra de Tavares, mapeando os sinais de um uso minoritário da língua.

Retomando a obra de Deleuze \& Guattari (2014), identifica-se que a primeira característica de uma literatura menor é a desterritorialização operada pela/na língua. Os autores lembram que "uma literatura menor não é a de uma língua menor, mas antes a que uma minoria faz em uma língua maior" (DELEUZE \& GUATTARI, 2014, p. 34) - e o exemplo clássico oferecido para demonstrar tal desterritorialização no interior de uma "língua maior" é o uso da língua alemã exercido por Kafka. Gonçalo M. Tavares também produz certos índices de desterritorialização em suas obras através de alguns mecanismos linguísticos e formais. Em Uma viagem à Índia, por exemplo, o artifício cartográfico contido no texto ao final dos dez cantos parece ter o objetivo de, ao contrário de ordenar 
a narração com seus pontos distribuídos pelo plano cartesiano, desterritorializá-la. As coordenadas deste itinerário da melancolia contemporânea são puramente linguísticas e implodem a sequência linear do texto, estabelecendo relações imprecisas entre o índice linguístico contido no "mapa", a nomear determinado ponto, e o poema correspondente a ser localizado no espaço poético-narrativo dos dez cantos.

$\mathrm{O}$ texto de Gonçalo M. Tavares é ambivalente em relação às noções de pertencimento subjacentes ao protagonista de Uma viagem à Índia, Bloom. A cadeia de negações estabelecida nas nove estrofes iniciais da referida obra parece se empenhar em provar ao leitor o quanto a narrativa que se inicia se pretende afastada dos grandes feitos da civilização e dos grandes acontecimentos da História, inaugurando, por hora, uma espécie de "epopeia" que se quer "ínfima" (TAVARES, 2010, p. 434) como afirma o próprio narrador/sujeito poético. Porém, tal adjetivo não lhe pretende conectar ao banal, à vida cotidiana (como o fizera Joyce, com seu Ulysses, focalizando-o durante um único dia de sua vida), mas reduzi-la e fragmentá-la numa operação quase que microscópica, íntima, interna, como se, diante de um filme de viagem, a operação desejada fosse a de dividi-lo em cada segundo de movimento, e, de posse de cada um destes hipotéticos segundos isolados, fragmentá-los ainda mais, em seus vinte e quatro fotogramas que, durante um segundo, produzem a ilusão do movimento. Isto é, operar a desmontagem, a desconstrução e, como consequência, a desterritorilização de cada uma destas imagens que nos revelariam " [...] as várias epopeias que existem / num só dia [...]"(TAVARES, 2010, p. 434) e, por fim, obter "a imobilidade como epopeia ínfima [...] - eis o que descobriu [Bloom] depois de estar cansado" (TAVARES, 2010, p. 434).

Em determinada estrofe de Uma viagem à Índia, o narrador/sujeito poético localiza o ponto de partida da viagem de Bloom, revelando seu endereço exato dentro da cidade de Lisboa, anteriormente à viagem. Ora, tal informação é "inútil" dentro da economia narrativa do texto, e só faz sentido caso seja lida ironicamente, confrontada com as deambulações mentais do protagonista, a efetiva viagem a que Bloom se lança nesta epopeia da imobilidade pelo tédio contemporâneo. Epopeia ínfima - e infame, em seus desdobramentos -, confronta o aparente pertencimento do protagonista a uma exata localização geográfica com a desterriorialização, o corte de todos os cordões umbilicais da civilização a ligar Bloom com o Homem, elaborada na proposição do texto. Ambivalentes, as duas operações falseiam a genealogia do protagonista, porque confirmam a sua ontológica conexão com a cultura, no abundante fluxo transtextual do narrado/do poetizado.

Bloom, enquanto sujeito individual que se opõe ao passado coletivo português pela subversão anti-epopaica operada em relação a seu referente hipotextual imediato, $O s$ lusíadas, agencia uma forma de enunciação coletiva dos sujeitos para além das noções de pátria e das fronteiras nacionais, problemática presente neste ainda recente século XXI. Uma viagem à Índia, enquanto manifestação pós-moderna de discurso épico, anula a ação da personagem, paralisando-a em uma viagem cuja narratividade é totalmente neutralizada, inativa, estanque, por mais contraditório que tais adjetivos possam parecer para caracterizar uma narrativa, justamente, de viagem, de modo a concentrar toda a potência da linguagem na corrosão do modelo épico a partir de seu interior, fazendo com que "a linguagem deixe de ser representativa para tender para seus extremos ou seus limites" (DELEUZE \& GUATTARI, 2014, p. 47, grifos dos autores).

As outras duas características da literatura menor, a saber, "a ligação do individual no imediato-político [e] o agenciamento coletivo da enunciação” (DELEUZE \& GUATTARI, 
2014, p. 39) também são marcas de Uma viagem à Índia. É interessante perceber a oscilação de vozes na enunciação do texto, que ora é emitida pelo narrador/sujeito poético; ora pelo protagonista Bloom ou (de modo menos frequente), por outra personagem; ora por uma instância que parece estar acima destas outras duas, uma entidade maior do texto que se dirige tanto às personagens como ao próprio narrador/sujeito poético em terceira pessoa, revelando uma consciência mais aguda da construção da obra: "É Bloom quem diz. Ou então Jean M. // De qualquer maneira, o narrador também fala" (TAVARES, 2010, p. 180). Eis que as vozes se imbricam na aclamação de um mundo "disforme" (TAVARES, 2010, p. 180), em que a indistinção destes sotaques esconde a enunciação desta quarta voz, que não é a de Bloom, nem a de Jean M, nem a do narrador. "([Mas], como saber quem diz o quê? E que importa?)" (TAVARES, 2010, p. 180). A oscilação de vozes na superfície do texto e a flagrante interferência lírica numa poesia que, a princípio, é predominantemente narrativa corroboram para que "não ha[ja] mais sujeito de enunciação nem sujeito de enunciado [...]. Mas um circuito de estados que forma um devir mútuo, no seio de um agenciamento necessariamente múltiplo ou coletivo" (DELEUZE \& GUATTARI, 2014, p. 45). A voz enunciativa que se sobrepõe à voz do narrador/sujeito poético e às vozes das personagens (quando a enunciação lhes é concedida) no corpo lírico-narrativo da obra cumpre a função de agenciar, na cartografia do itinerário da melancolia contemporânea (desmontando a ficção, desterritorializando o poema), as entidades líricas/poéticas que constituem a constelação de poesias das mais de quatrocentas páginas.

Para Deleuze \& Guattari, “a metamorfose é o contrário da metáfora. Não há mais sentido próprio nem sentido figurado, mas distribuição de estados no leque da palavra. A coisa e as coisas não passam de intensidades percorridas pelos sons ou as palavras desterritorizalizadas seguindo sua linha de fuga" (2014, p. 45). Tavares abole as metáforas de seu texto, estabelecendo cadeias metonímicas que podem ser verificadas tanto no interior das estrofes quanto na cartografia construída ao final do texto, na qual muitos dos substantivos se repetem, apontando para posições dispares dentro dos cantos. Ou seja, as repetições são "falsas" repetições, porque jamais correspondem a mesma estrofe, como se fossem desdobramentos diferentes de um mesmo termo, isto é, termos que sofrem metamorfose ao serem confrontados com seus referentes poéticos, a exemplo do que ocorre com a palavra "amor": "amor", correspondendo ao poema da trigésima sexta estrofe do segundo canto; "amor", ao poema da vigésima estrofe do terceiro canto; "amor", ao poema da quinquagésima primeira estrofe do quinto canto; "amor", ao poema da sétima estrofe do sétimo canto; e, "amor", correspondendo ao trigésimo segundo poema do nono canto.

Há um estado animalesco a encampar inúmeras palavras, versos e estrofes durante os dez cantos. E também um estado maquínico (antes da própria "máquina" formada pelo texto em si, há, na sua construção, índices maquínicos do agenciamento que ele constituiu). Tais devires, o animal e o de máquina, parecem se conectar através de um desejo de ruído que a natureza emite, mas que a máquina não consegue fazer por estar defeituosa. Assim: na cartografia que constitui o "itinerário" da "melancolia contemporânea", um dos únicos adjetivos é animalesco, a apontar para a estrofe vinte e quatro do canto VI, na qual se lê que "[...] debaixo das estradas e dos estabelecimentos comerciais / há uma vida animal que persiste / e faz ruído" (TAVARES, 2010, p. 252); ora, um dos índices a percorrer toda a obra é o velho rádio do pai que Bloom carrega no bolso do casaco, um rádio que, por não funcionar, não emite qualquer som, mas que lhe é fundamental. Causa estranhamento tal fato, pois um rádio estragado não serviria para 
absolutamente nada durante uma viagem. Porém, para Bloom, que vive como quem perdera "[...] o norte, o sul e o resto", o rádio do pai, "velho e antigo e, como sempre, avariado" é "a sua referência [...]" (TAVARES, 2010, p. 421).

A forma com que Bloom assassinara o pai também revela profunda animalidade. Ele o fizera com um pequeno punhal, como se o pai fosse um animal a ser sacrificado. E quando assassina uma prostituta, assim o faz com uma pancada na cabeça da vítima, também sugerindo o abatimento de um animal. A imobilidade da morte, e também do sono, acaba por operar a metamorfose deste devir animal: todos morrem, todos dormem, sejam eles "ratos, sapos, pássaros, minhocas, doninhas, / a baleia, cabras de chifres diversos, até aracnídeos, / tudo quanto é bicharada [...]. [Ou] presidente, / carpinteiro, santo supérfluo, criminoso necessário, / carteiro coxo, corredor de automóveis, paralíticos, multidões em fúria" (TAVARES, 2010, p. 91-92)

A conversão da literatura em "máquina de expressão" (DELEUZE \& GUATTARI, 2014, p. 39) só é possível pelo movimento de desterritorialização da língua, e, para realizálo, Deleuze \& Guattari elencam duas formas possíveis: a primeira seria "enriquece[-la] artificialmente, infl[á-la] de todos os recursos de um simbolismo, de um onirismo, de um senso esotérico, de um significante escondido" (2014, p. 39-40), o que fizeram os autores da escola de Praga, de acordo com os teóricos. A segunda forma é aquela escolhida (inventada) por Kafka: “Optar pela língua alemã de Praga, tal como ela é, em sua pobreza mesma. [...] Já que o vocabulário é ressecado, fazê-lo vibrar em intensidade. Opor um uso puramente intensivo da língua a todo uso simbólico" (2014, p. 40). Um segundo exemplo que permite reconhecer a literatura em sua potência de "máquina de expressão", e revela estes dois usos da língua, está em Joyce e Beckett. Para Deleuze \& Guattari, os "dois, irlandeses, estão nas condições ideais de uma literatura menor" (2014, p. 40) porém, enquanto Joyce "não cessa de proceder por exuberância e sobrederterminação, e opera[r] todas as reterritorializações mundiais" (2014, p. 40), Beckett "[no uso do inglês e do francês] procede por força de secura e de sobriedade, de pobreza querida, empurrando a desterritorialização até que não subsistam mais que intensidades” (2014, p. 40).

Em Kafka, as engrenagens desta "máquina de expressão", a saber, as cartas, as novelas e os romances, correspondem a três forças imanentes a cada uma delas: as cartas, ao estabelecerem um "pacto diabólico", correspondem ao medo; as novelas, ao encaparem um "devir-animal", correspondem à fuga; e, os romances, ao produzirem um "agenciamento maquínico", correspondem à desmontagem. Aceitar a possibilidade de ler Uma viagem à Índia sob o viés de um romance versificado, como sugere Eduardo Lourenço no prefácio à primeira edição da obra, significa acolher as mesmas engrenagens que constituem a exemplar obra de Kafka, e reconhecer na ficção tavaraiana a sua potência de desmontagem da forma e da linguagem; e, perceber que Bloom é um protagonista parricida em fuga, numa vigem travestida pela busca de sabedoria e de esquecimento, como explica o narrador; e que, como tal, é marcado pelo medo de confrontar os seus crimes perante a lei e pela necessidade de dar algum rumo para o nonsense trágico no qual sua vida se convertera.

O narrador/sujeito poético deseja uma "suspensão" da natureza, "[...] entrar num sítio onde [ela] não existisse [...]” (TAVARES, 2010, p. 255). Para tanto, há a necessidade de "[...] uma máquina / que excluísse todas as matérias naturais [...]" (TAVARES, 2010, p. 255). Tal máquina seria "uma máquina literária" (TAVARES, 2010, p. 255), a máquina capaz de cumprir o desejo de uma suspensão da natureza enquanto realidade narrável. 
Porém, em todo lugar em que as letras pousam há a abundância de "partículas naturais" (TAVARES, 2010, p. 255), tudo está contaminado pela natureza, pela realidade. Ou seja, a única forma para manter a adequada assepsia da produção desta máquina seria dispô-la sobre o "Nada", porém, mesmo o "Nada", para o narrador/sujeito poético, é algo "natural". As duas "parábolas" contidas no primeiro canto de Uma viagem à Índia, de filiação bastante kafkiana, constituem exemplos metaliterários dessa tentativa de obtenção do "Nada" através da máquina literária. Ambas são imponderáveis e lacunares: na primeira delas, um homem mata um esgrimista em meio a uma multidão louca e corre infinitamente para alcançar uma linha imaginária; na segunda, um homem avança por uma floresta até chegar numa rua em que olha para todos os lados, menos para cima.

O desejo é o combustível a alimentar esta máquina de linguagem que se prolifera em outras pequenas máquinas dentro do texto, num devir-máquina; e, em extensas elucubrações sobre o animal ao longo dos dez cantos, num devir-animal, de modo que "a escrita tem esta dupla função: transcrever em agenciamentos, desmontar os agenciamentos. Os dois são um só" (DELEUZE \& GUATTARI, 2014, p. 87). Tal desejo é ambivalente, uma vez que o seu exercício está a revelar a sua interdição: desejo também é anti-desejo, contra-desejo, num movimento semelhante ao que ocorre com a ação do protagonista, no qual a ação é também inoperância, inação. As figuras femininas do texto podem ser um indício deste desejo exasperado/desejo interditado. As mulheres com quem Bloom se relaciona são sempre prostitutas. As únicas exceções são a mãe e Mary, a amada. Porém, elas são apenas citadas no texto, de modo que não há a narração de nenhum contato efetivo com elas: a narrativa, quando de seu início, traz Mary já assassinada pelo pai de Bloom; a mãe é apenas mencionada em duas minúsculas passagens, a segunda delas quando o protagonista é avisado de que ela já está morta. De resto, é com as prostitutas que Bloom desenvolve seu "amor" e realiza seus “desejos", inclusive os mais degradantes e animalescos, como a violência física, a resultar em assassinato. Bloom ignora a lei e a justiça, e o narrador/sujeito poético parece também as ignorar, como se "ali onde se acredita[sse] que havia lei, há de fato desejo e somente desejo. A justiça é desejo, e não lei” (DELEUZE \& GUATTARI, 2014, p. 91, grifos dos autores).

Ainda é possível mapear três elementos que exemplificam este "desejo" e a sua interdição. O primeiro deles ainda se relaciona com o devir-máquina engendrado pela/ na máquina de linguagem que é o próprio texto: o já citado velho rádio do pai, que jamais funcionara, mas que também jamais foi abandonado por Bloom. O rádio, como uma espécie de pequena máquina de linguagem (in)operada pela/na grande máquina de linguagem que é a obra, simplesmente não funciona, ou seja, não dispõe de sua capacidade de transmitir/re-produzir linguagem, muito embora seja um fundamental elemento de referencialidade para Bloom dentro de sua aparente inutilidade. $\mathrm{O}$ segundo se refere ao nome da amada, Mary (Maria). Dentro da cultura Ocidental, o nome "Maria" é extremamente significativo, uma vez que, no Novo Testamento, nomeia a Virgem que deu à luz ao messias por intervenção do Espírito Santo. O último elemento é a relação edipiana nitidamente estabelecida entre Bloom e o pai, por ele assassinado.

Diante deles, o leitor experimenta a ação de "máquinas abstratas". Abstratas, porém corrosivas (ou corrosivas porque abstratas), tais máquinas, miniaturizadas na forma das parábolas mencionadas, demonstram o poder subversivo do texto tavariano e a operação que ele executa no interior do discurso que engendra: equação que torna a sua língua "menor", desterritorializada, em relação àquela utilizada nas epopeias clássicas, de nítida 
exuberância celebratória de uma História fixa e localizável; e que, consequentemente, produz uma espécie de forma "menor", desmontada, corroída em seu íntimo, da qual emerge uma plêiade de vozes enunciativas no encadeamento da narração, face à nítida "história" que engendra, e também uma voz supra-consciente a se impor ao próprio narrador constituído como tal, estância responsável pela "montagem", pela "organização" das centenas de poemas no corpo da obra, cuja síntese é apresentada no "itinerário" final, o atlas íntimo e subjetivo que encerra o corpo do livro. Verdadeira "máquina de expressão", "máquina literária", a epopeia de Tavares não consegue encampar o "Nada" na busca de uma total assepsia do mundo objetivo, desejo revelado (ironicamente?) pelo narrador/sujeito poético, porém opera o seu inverso, o alcance de um "tudo" dentro da cultura Ocidental, para tão logo subvertê-la, minorizá-la.

\section{Considerações finais}

Eis que a desterritorialização operada pela (anti)epopeia tavariana surge desde logo no começo do texto com sua cadeia de negações a respeito de uma "inevitável" filiação à civilização ocidental, negando toda grandeza de uma História que pretendia seguir os rumos do progresso, admitindo ser apenas algo muito pequeno, "epopeia ínfima". Bloom, enquanto homem individual e destituído de todo heroísmo coletivo, opõe-se ao passado nacional pelas subversões operadas no texto camoniano e textualizadas em Uma viagem à Índia, agenciando uma forma de enunciação coletiva dos sujeitos que rompe a noção de pátria e patriotismo, alocando o problema da enunciação para além das fronteiras nacionais, como quem prevê o drama dos imigrantes na Europa, oriundos de diferentes países, a procura de algum reconhecimento de sua humanidade. Está dada a ligação do individual no imediato-político e o agenciamento coletivo da enunciação: no texto de Tavares, as instâncias enunciativas se confundem, as vozes do narrador, do protagonista, das personagens e de um sujeito que parece estar acima do próprio narrador entram em colisão e não são facilmente detectáveis. Muitas vezes não se sabe quem diz o que. Porém o texto questiona o leitor: "E que importa?"

A obra opta pela metamorfose em vez da metáfora. As cadeias metonímicas podem ser verificadas tanto no interior das estrofes quando no "planisférios literário". Nele, elas ficam muito claras, a exemplo do que ocorre com o substantivo "amor" e suas correspondências no corpo versificado do texto. Em suas reincidências, o termo e as imagens que evoca metamorfoseiam e mobilizam novos sentidos, novas imagens. Muitas das expressões, imagens, episódios e símbolos são encampados por um estado animalesco e um estado maquínico. Vale lembrar a constante redução do homem a um mero "mamífero"; a redução da cultura humanista e da racionalidade positiva aos designíos da natureza e/ou da desmedida busca pela materialidade; a presença do velho rádio do pai, avariado, mas do qual o protagonista jamais se afasta; o leite, que não remete mais ninguém à vaca, cujo sabor lembra as fábricas.

Diante de todos estes aspectos, a síntese a que chego é a de que Uma viagem à Índia, obra publicado em 2010 pelo escritor português Gonçalo M. Tavares, incorpora a potência de uma verdadeira "máquina de expressão", a exemplo daquilo em que se convertera a literatura de incontornáveis autores, tais como Kafka e Beckett, ambos citados por Deleuze \& Guattari para elucidar o conceito de "literatura menor", e com os quais a obra de Tavares estabelece amplo diálogo. A (anti)epopeia tavariana exerce sua força 
de "desmontagem" sobre as engrenagens discursivas da épica camoniana, desejando se deslocar para o mais longe possível desta sua irmã siamesa em conflito. No entanto, não há como lhe virar as costas. O que resta a ela é acatar a similitude genética e a disparidade temperamental que há entre ambas, e se afirmar, no campo dos estudos literários, maior por meio de sua "poética menor".

\section{Referências}

BARTHES, R. A câmara clara. Lisboa: Edições 70, 2006. Trad. Júlio Castañon Guimarães.

BENJAMIN, W. O narrador. Considerações sobre a obra de Nikolai Leskov. In: Magia e técnica, arte e política. São Paulo: Brasiliense, 1994. Trad. Sergio Paulo Rouanet.

DELEUZE, G.; GUATTARI, F. Kafka: por uma literatura menor. Belo Horizonte: Autêntica, 2014. Trad. Cíntia Vieira da Silva.

DIDI-HUBERMAN, G. Sobrevivência dos vaga-lumes. Belo Horizonte: UFMG, 2011. Trad. Vera Casa Nova e Márcia Arbex.

GENETTE, G. Palimpsestes: la littérature au second dégrée. Paris: Seuil, 1982.

JOYCE, J. Ulysses. São Paulo: Penguin Classics Companhia das Letras, 2012. Trad. Caetano W. Galindo.

LOURENÇO, E. Uma viagem no coração do caos. In.: TAVARES, G. M. Uma viagem à Índia: melancolia contemporânea (um itinerário). São Paulo: Leya, 2010.

MARTELO, R. M. Opacidades, ou nem tanto (um exemplo). In: Vidro do mesmo vidro: Tensões e deslocamentos na poesia portuguesa depois de 61. Porto: Campo das Letras, 2007.

ROCHE, D. La disparition des lucioles: réflexions sur l'acte photographique. Paris: Éditions de l'Étoile, 1982.

TAVARES, G. M. Uma viagem à Índia - Melancolia contemporânea (um itinerário). São Paulo: Leya, 2010. 